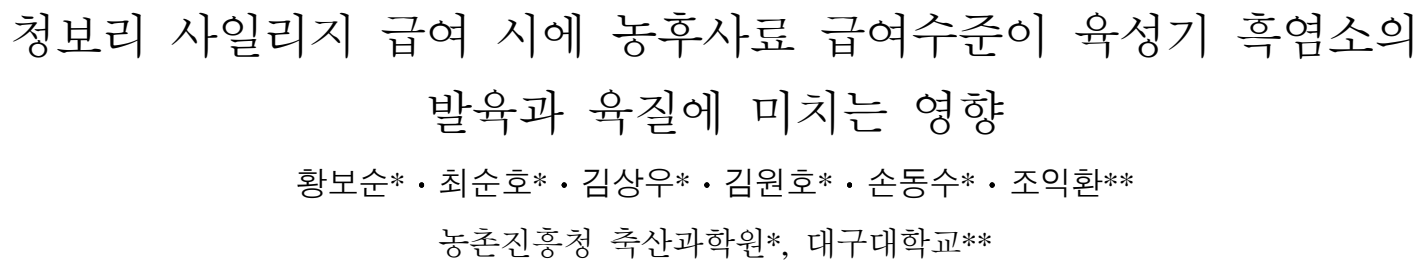

\title{
Effects of Dietary Concentrate Levels Based on Whole-Crop Barley Silage on Growth and Meat Quality in Growing Korean Black Goats
}

\author{
Soon Hwangbo*, Sun Ho Choi*, Sang Woo Kim*, Won Ho Kim*, Dong Soo Son* \\ and Ik Hwan Jo** \\ National Institute of Animal Science, R.D.A.*, Daegu University**
}

\begin{abstract}
Effects of dietary concentrate levels based on whole-crop barley silage (BS) on development and meat quality in growing Korean black goats were examined. A total of 36 male goats with similar age and BW were equally allocated to dietary four treatments in a randomized complete block design. Dietary treatments included controls (rice straw ad libitum plus $2.0 \%$ concentrate $\mathrm{BW}^{-1}$ ), and $\mathrm{BS}$ ad libitum plus three increasing levels of concentrate $\mathrm{BW}^{-1}(2.0,1.5$ and $1.0 \%$, respectively), expressed as BS 2.0, BS 1.5 and BS 1.0, respectively. The trial was lasted for 5 months from 14th of May to 12th of October, 2007. At the end of trial, all animals were slaughtered to analyze carcass characteristics and meat quality. Average daily gain was significantly $(\mathrm{p}<0.05)$ higher for BS 1.5 and BS 2.0 treatments than for controls. Daily feed intakes for controls $(689.3 \mathrm{~g})$ were significantly $(\mathrm{p}<0.05)$ higher than those of BS $1.0(585.5 \mathrm{~g})$, but they were significantly $(\mathrm{p}<0.05)$ lower than BS $2.0(734.3 \mathrm{~g})$. Carcass and meat percentages were significantly $(\mathrm{p}<0.05)$ higher for BS 2.0 and BS 1.5 than for control and BS 1.0 treatments. Shear force and water-holding capacity was greater $(\mathrm{p}<0.05)$ for BS 2.0 and BS 1.5 than other treatments. On the basis of feeding whole-crop barley silage to Korean black goats, as dietary concentrate inclusion levels increased, sensory results showed to have a better tendency. In conclusion, it was estimated that the optimal level of dietary concentrates might be $1.5 \% \mathrm{BW}^{-1}$, when diets based whole-crop barley silage were fed to growing Korean black goats for their improvements of growth and meat quality.

(Key words : Whole-crop barley silage, Concentrate, Growth, Meat quality, Goats)
\end{abstract}

\section{I. 서 론}

흑염소 고기는 일반 육류와는 달리 주로 약 용으로 인식되어 증탕으로 가공되어 건강보조
식품으로 소비되어 왔으나, 최근 외식산업의 발달과 함께 음식문화도 다양화되고, 고급화되 면서 흑염소 고기의 소비량 증가와 흑염소 요 리전문 음식점이 늘어나고 있는 추세이다. 그

Corresponding author : Sun Ho Choi, Animal Genetic Resources Station, National Institute of Animal Science, R.D.A, Namwon, 590-830, Korea.

Tel : (063)620-3530, E-mail : choi7804@rda.go.kr 
러나, 근래 국제 곡물가격의 급등으로 국내 배 합사료 가격이 폭등함에 따라 흑염소 사육에도 어려움이 가중되고 있어 생산비 절감을 위한 다각적인 자구책이 강구되고 있다.

한편, 국내 조사료 생산현실은 초지생산 기 반이 취약하고 사료작물의 재배면적 또한 지속 적으로 감소하고 있으며, 외국으로부터 막대한 양의 조사료까지 수입하고 있는 실정이다. 또 한, 국내에 자급되는 조사료조차도 대부분 사 료가치가 낮은 볏짚이며, 목초 및 사료작물과 같은 양질의 조사료 비중은 낮아지고 있어 축 산업의 경쟁력 강화에 큰 걸림돌이 되고 있다.

최근, 양질 조사료 확보를 위해 사료작물 재 배에 대한 연구가 활발히 추진되고 있다. 특히, 사일리지용 청보리는 ha 당 건물수량이 호밀과 이탈리안 라이그라스와 비슷하고, TDN 함량이 $65 \%$ 내외이며, 황숙기로 갈수록 에너지 함량이 높아진다(김 등, 2003)고 보고하여 청보리의 사 료가치 우수성을 시사하였다.

청보리 사일리지를 이용한 연구 결과는, 거 세 한우에 있어서 일당증체량과 육질이 볏짚 급여 시 보다 향상되었고, Holstein의 착유 시험 에서도 볏짚 시험구 보다 산유량과 유지방이 증가한다고 하였으며 (김과 서, 2006), 또한 청 보리 사일리지에는 알곡이 포함되어 에너지가 가 높아 겨울철 포유우의 높은 요구에너지를 충족시킬 수 있다(Manninen 등, 2008)고 하여 청보리 사일리지의 가축급여 효과가 뛰어남을
보고하였다.

따라서, 본 시험에서는 청보리 사일리지를 육성기 흑염소에게 급여하였을 때 농후사료 급 여수준이 흑염소의 발육과 육질에 미치는 영향 을 조사하여 청보리 사일리지의 급여효과와 농 후사료의 적정 급여수준을 구명하고자 실시하 였다.

\section{․ 재료 및 방법}

\section{1. 공시가축 및 시험장소}

본 시험에 이용된 공시가축은 생후 6 개월령 의 흑염소 수컷으로 체중 $17 \mathrm{~kg}$ 내외의 36 두를 처리구별로 각각 9 두씩 공시하였고, 시험기간 은 2007년 5월 14일부터 2007년 10월 12일까지 152 일간 농촌진흥청 축산과학원 가축유전자원 시험장에서 수행하였다.

\section{2. 공시사료 및 시헙축의 사양관리}

본 시험의 처리는 시판사료를 체중의 2.0 (BS 2.0구), 1.5 (BS 1.5구) 및 1.0\%(BS 1.0구)로 하 여 조사료원은 청보리 사일리지를 자유급식 시 켰고, 대조구는 시판사료의 급여 수준을 $2.0 \%$ 로 하고 볏짚을 자유급식 시켰으며, 시험사료 의 일반성분은 Table 1 과 같다. 사료 급여는 시 험사료 적응을 위하여 본시험 실시전 15 일간

Table 1. Chemical composition of ingredient diets fed to Korean black goats (\%, DM)

\begin{tabular}{lccc}
\hline Items & $\begin{array}{c}\text { Whole-crop barley } \\
\text { silage }\end{array}$ & Rice straw & Concentrate \\
\hline \hline Dry matter (\%) & 41.5 & 89.85 & 90.00 \\
Composition of DM & & & \\
Crude protein (\%) & 8.11 & 6.40 & 15.15 \\
Acid detergent fiber (\%) & 34.94 & 40.27 & 16.40 \\
Neutral detergent fiber (\%) & 57.89 & 69.99 & 39.02 \\
Ether extracts (\%) & 3.10 & 0.85 & 3.88 \\
Crude ash (\%) & 7.91 & 6.87 & 6.75 \\
Non-fibrous carbohydrate (\%) & 22.99 & 15.89 & 35.20 \\
\hline
\end{tabular}


적응기간을 두었으며, 시험개시부터는 오전 9 시와 오후 4시경에 균등하게 나누어 급여하였 다. 시험축의 사양관리는 처리구별로 3두씩 3 반복하여 총 36 두를 케이지에 수용하여 사양을 하였고 물은 자동급수기를 이용하여 신선한 물 을 자유롭게 먹을 수 있도록 하였다.

\section{3. 체중 및 사료섭취량}

체중은 시험 시작일에 개시체중을 측정하였 고 시험 종료시까지 30 일 간격으로 사료급여 전에 측정하였으며, 사료섭취량은 사료급여량 을 측정하고 급여한 후 다음날 첫 사료급여 전 에 잔량을 측정한 다음 급여량에서 잔량을 제 한 값을 사료섭취량으로 계산하였다.

\section{4. 도체 및 육질조사}

도체조사는 시험종료 후 각 처리구별로 5 두 씩 축산과학원 축산물이용과 육가공 연구실에 서 탕박 처리로 도축하여 $5^{\circ} \mathrm{C}$ 에서 24 시간 냉장 시킨 후 발골하여 도체중, 정육량, 뼈, 지방의 중량을 전자저울을 이용하여 측정하였고, 육질 은 처리구당 3 두씩 3반복으로 9점의 시료를 등
심과 채끝에서 채취하여 등심근은 일반조성분 그리고 채끝은 전단력을 조사하는데 이용하였 다. 일반조성분은 A.O.A.C. (1990) 방법에 준하 여 분석하였으며, 가열감량, 전단력 (WarnerBratzler shear meter, G-R Elec. Mfg. Co. USA) 을 조사하였고, 관능검사는 검사요원 10 명을 무작위로 차출하여 처리별로 다즙성, 연도, 향 미에 대하여 기호도 6점 만점으로 하여 조사하 였다.

\section{5. 통계 분석}

통계분석은 SAS (Statistical Analysis System Institute Inc. 1991) package를 이용하여 분석하 였으며, 처리간 유의성은 Duncan's multiple range test (5\% 수준)를 이용하여 검정하였다.

\section{II. 결과 및 고찰}

\section{1. 증체량 및 사료섭취량}

청보리 사일리지 급여 시 농후사료 수준을 달리하여 급여하였을 때 육성기 흑염소의 증체 량 및 사료섭취량에 미치는 영향은 Table 2와

Table 2. Effects of dietary concentrate levels based on whole-crop barley silage on body weight gain and dry matter intake in Korean black goats

\begin{tabular}{|c|c|c|c|c|}
\hline Treatment $^{1)}$ & Control & BS 2.0 & BS 1.5 & BS 1.0 \\
\hline Initial body weight (kg) & $17.47 \pm 1.82$ & $17.80 \pm 0.61$ & $17.61 \pm 1.90$ & $17.50 \pm 0.78$ \\
\hline Final body weight (kg) & $28.48 \pm 1.36^{\mathrm{bc}}$ & $32.11 \pm 0.54^{\mathrm{a}}$ & $30.03 \pm 1.51^{\mathrm{b}}$ & $27.67 \pm 0.57^{\mathrm{c}}$ \\
\hline Total gain (kg) & $11.02 \pm 0.46^{\mathrm{c}}$ & $14.31 \pm 0.07^{\mathrm{a}}$ & $12.41 \pm 0.52^{\mathrm{b}}$ & $10.16 \pm 0.48^{\mathrm{d}}$ \\
\hline ADG (g/day) & $72.96 \pm 3.08^{c}$ & $94.77 \pm 0.46^{\mathrm{a}}$ & $81.86 \pm 3.31^{\mathrm{b}}$ & $67.33 \pm 3.18^{\mathrm{d}}$ \\
\hline TDMI (g/day) & $689.3 \pm 16.2^{\mathrm{b}}$ & $734.3 \pm 12.4^{\mathrm{a}}$ & $692.2 \pm 18.1^{\mathrm{b}}$ & $585.5 \pm 13.6^{c}$ \\
\hline - rice straw, barley silage & $228.2 \pm 12.0^{c}$ & $270.2 \pm 14.8^{\mathrm{b}}$ & $340.9 \pm 14.2^{\mathrm{a}}$ & $352.2 \pm 15.6^{\mathrm{a}}$ \\
\hline - concentrate & $461.1 \pm 4.29^{\mathrm{a}}$ & $464.1 \pm 2.71^{\mathrm{a}}$ & $351.3 \pm 3.89^{b}$ & $233.3 \pm 1.99^{c}$ \\
\hline \multicolumn{5}{|l|}{ Feed conversion ratio } \\
\hline TDMI/ADG (g/g) & $9.45 \pm 0.28^{\mathrm{a}}$ & $7.75 \pm 0.11^{\mathrm{c}}$ & $8.46 \pm 0.14^{b}$ & $8.70 \pm 0.21^{\mathrm{b}}$ \\
\hline
\end{tabular}

1) Control: Rice straw+concentrate $2.0 \%$,

BS 2.0: Whole-crop barley silage+concentrate 2.0\%, BS 1.5: Whole-crop barley silage+concentrate $1.5 \%$,

BS 1.0: Whole-crop barley silage+concentrate 1.0\%, ADG: Average daily gain. TDMI: Total dry matter intake. Data are expressed as mean \pm SD.

a,b,c,d Values with different superscripts within the same row are significantly $\operatorname{different}(\mathrm{p}<0.05)$. 
같다.

시험기간 동안 처리구별 일당증체량은 67.33 $\sim 94.77 \mathrm{~g}$ 의 범위로 나타났으며, 볏짚과 농후사 료를 체중의 $2 \%$ 로 급여한 대조구 보다 청보리 와 농후사료를 1.5 와 $2.0 \%$ 급여구가 유의하게 높게 나타났다 $(\mathrm{p}<0.05)$. 1 일 사료 섭취량은 대 조구가 $689.3 \mathrm{~g}$ 으로 BS 1.0 구의 $585.5 \mathrm{~g}$ 보다 유 의하게 높았지만, BS 2.0 구의 $734.3 \mathrm{~g}$ 보다는 유 의하게 낮게 섭취하였다 $(\mathrm{p}<0.05)$. 사료요구율은 대조구가 9.45으로 가장 높았고, 청보리를 급여 한 구는 농후사료 급여수준이 높을수록 유의하 게 낮게 나타났다 $(\mathrm{p}<0.05)$.

김과 서(2006)는 거세 한우에게 청보리 사일 리지 급여 시, 육성기 일당증체량이 볏짚 급여 시 $0.51 \mathrm{~kg}$ 보다 $65 \%$ 높은 $0.84 \mathrm{~kg}$ 의 증체를 보 였고, 이 시기에 조사료 섭취량은 볏짚 보다 청보리 사일리지가 $0.64 \mathrm{~kg}$ 높았지만, 농후사료 는 볏짚 급여구 $6.39 \mathrm{~kg}$, 청보리 사일리지 급여 구 $4.45 \mathrm{~kg}$ 섭취로 볏짚구보다 농후사료가 $35 \%$ 절감 되었다고 보고하였다. 본 결과에서도 육 성기 흑염소에 있어서 농후사료 $1.5 \%$ 급여한 청보리 사일리지구가 농후사료 $2.0 \%$ 급여한 볏 짚구 보다 총섭취량은 비슷했으나, 일당증체량 은 $11 \%$ 가 높아 발육 개선효과와 농후사료 절 감 효과가 나타나, 사료가치가 낮은 볏짚 보다 청보리 사일리지의 가축급여 효과가 높음을 시 사하였다.

한편, 본 결과에서 청보리 사일리지구간 농 후사료급여 비율이 높을수록 일당증체량이 유 의하게 높게 나타났는데, 이는 Baladi 염소 (Haddad, 2005), 양 (Mahgoub 등, 2000) 및 소 (Meissner 등, 1995) 등의 반추가축에서 농후사 료 수준이 높을수록 일당증체량이 높아진다는 결과와 일치하였다. 또한 Mazumder 등 (1998)은 육성기 양에게 농후사료 수준을 달리하여 6개 월 사양시험을 했을 때 농후사료 수준이 높을 수록 유의한 증체를 보였다고 보고하여 본 시 험과 유사한 결과였다.

농후사료 수준을 동일하게 급여한 대조구와 BS 2.0 구의 조사료 섭취량은 청보리 사일리지 를 급여한 BS 2.0 구가 유의하게 높았는데, 이 에 대해 조사료의 품질이 우수할수록 섭취량이
증가 (Shaver 등, 1988)하고 조사료의 섬유소 함 량이 높을수록 장내 체류시간이 길어져 사료섭 취량이 감소(Lippke, 1980)하며, 볏짚의 높은 $\mathrm{NDF}$ 함량 (Table 1)이 건물섭취량의 제한인자 (Van Soest, 1994)로 작용한다는 보고와 유사한 결과로 상대적으로 볏짚이 청보리 사일지지 보 다 사료가치가 낮아 BS 2.0 구의 조사료 섭취량 이 증가된 것으로 사료된다.

Archimede 등 (2008)은 체중이 $20 \mathrm{~kg}$ 인 4개월 령의 Ovin martinik 양에게 농후사료 수준을 $0 \mathrm{~g}$ 에서 $600 \mathrm{~g}$ 으로 증가 시에 조사료 섭취량은 $917 \mathrm{~g}$ 에서 $618 \mathrm{~g}$ 으로 감소하였으나 총 섭취량은 $917 \mathrm{~g}$ 에서 $1,140 \mathrm{~g}$ 으로 증가하였고, Kawas 등 (1991)도 자넨 교잡 유산양의 사일리지 급여시 험에서 농후사료 증가 시에 사료섭취량은 직선 적으로 증가한다고 보고하여, 청보리 사일리지 급여구간에 농후사료 수준이 증가할수록 조사 료 섭취량은 유의하게 낮아졌으나 총섭취량은 증가한 본 시험의 결과와 유사하였다.

\section{2. 도체 특성}

청보리 사일리지 급여 시 농후사료 수준을 달리하여 급여하였을 때 육성기 흑염소의 도체 특성에 미치는 영향은 Table 3과 같다.

도체율은 BS 2.0과 BS 1.5 구가 각각 52.61과 $52.28 \%$ 로 대조구와 BS 1.0 구의 각각 49.97과 $50.23 \%$ 보다 유의하게 높게 나타났다 $(\mathrm{p}<0.05)$. 정육율에서도 $\mathrm{BS} 2.0$ 과 $\mathrm{BS} 1.5$ 구가 대조구와 BS 1.0 구 보다 유의하게 높게 나타났다 ( $\mathrm{p}<$ 0.05). 지방율은 3.09 4.32\%의 범위로 유의적 차이는 없었지만 BS 2.0 과 BS 1.5 구가 높은 경 향으로 나타났다. 뼈 비율은 20.28 20.55\%로 처 리구간에 차이가 나타나지 않았다.

흑염소 도체율에 대해 최 등 (2007)은 사료에 너지 수준을 달리한 실험에서 $48.64 ~ 51.36 \%$ 이 었고, 농후사료 수준을 달리 급여한 Boer 잡종 염소의 도체율은 41.8 51.3\%로 보고(Ryan 등, 2007)하여, 49.97 52.61\%의 범위로 나타난 본 시험의 결과와 비슷한 수준이었다.

또한 본 시험에서 농후사료 수준이 증가할수 록 도체율과 정육율이 유의하게 높았는데, 이 
Table 3. Effects of dietary concentrate levels based on whole-crop barley silage on carcass characteristics in Korean black goats

\begin{tabular}{lcccc}
\hline \multicolumn{1}{c}{ Treatment $^{1)}$} & Control & BS 2.0 & BS 1.5 & BS 1.0 \\
\hline \hline Slaughter weight (kg) & $27.33 \pm 1.15$ & $27.67 \pm 0.58$ & $26.83 \pm 0.57$ & $26.33 \pm 0.58$ \\
Cold carcass weight (kg) & $13.66 \pm 0.61$ & $14.56 \pm 1.14$ & $14.03 \pm 0.58$ & $13.23 \pm 0.76$ \\
Dressing percentage (\%) & $49.97 \pm 0.50^{\mathrm{b}}$ & $52.61 \pm 0.50^{\mathrm{a}}$ & $52.28 \pm 0.32^{\mathrm{a}}$ & $50.23 \pm 0.60^{\mathrm{b}}$ \\
Meat percentage (\%) & $57.34 \pm 1.12^{\mathrm{b}}$ & $61.26 \pm 1.02^{\mathrm{a}}$ & $60.03 \pm 0.63^{\mathrm{a}}$ & $57.68 \pm 0.75^{\mathrm{b}}$ \\
Fat percentage (\%) & $3.09 \pm 0.87$ & $4.32 \pm 0.88$ & $4.04 \pm 0.60$ & $3.78 \pm 0.56$ \\
Bone percentage (\%) & $20.48 \pm 0.68$ & $20.28 \pm 0.71$ & $20.29 \pm 0.86$ & $20.55 \pm 0.52$ \\
\hline
\end{tabular}

1) Control: Rice straw+concentrate $2.0 \%$,

BS 2.0: Whole-crop barley silage+concentrate $2.0 \%$, BS 1.5: Whole-crop barley silage+concentrate 1.5\%, BS 1.0: Whole-crop barley silage+concentrate $1.0 \%$ Data are expressed as mean \pm SD.

a,b Values with different superscripts within the same row are significantly different $(\mathrm{p}<0.05)$.

러한 결과는 방목 시 농후사료 수준이 증가함 에 따라 도체율이 증가하고(Rhee 등, 2000), 양 에 있어서도 사료의 비율이 조사료 보다 농후 사료가 증가함에 따라 도체율과 정육율이 증가 한다 (Mahgoub 등, 2000)는 보고와 일치하였다.

한편, 본 실험에서 뼈 비율과 지방율에서 유 의적 차이는 인정되지 않았지만 농후사료 수준 이 높은 BS 2.0 과 BS 1.5 구가 지방율이 높은 경향으로 나타났었는데, 이는 가축이 성장단계 에서 다른 조직보다 골격 형성이 먼저 이루어 지기 때문에 뼈 비율에서는 차이가 없고(ColomerRocher 등, 1992), 영양수준에 따라 지방율의 차이 (Atti 등, 2004; Burke 등, 2003)가 있기 때 문이라 사료된다.

\section{3. 육질 특성}

청보리 사일리지 급여 시 농후사료 수준을 달리하여 급여하였을 때 흑염소 고기의 일반조 성분에 미치는 영향은 Table 4 와 같다. 흑염소 고기의 수분과 단백질은 각각 75.09 75.64와 21.01 22.24\%의 범위로 나타났으며, 조지방은 1.56 1.86\%의 범위로 유의성은 나타나지 않았 지만 BS 2.0 과 1.5 구가 높은 경향이었다. 조회 분 함량은 $1.04 ~ 1.19 \%$ 의 범위로 처리간 비슷하 게 나타났다.

염소 고기의 일반성분에 대해 Devendra (1988) 은 수분이 74.2 76\%, 단백질 함량은 20.6 22.3 $\%$, 지방은 $0.6 \sim 2.6 \%$, 회분은 $1.1 \%$ 이며, 최 등 (2005; 2007)은 흑염소 고기의 수분, 단백질, 지

Table 4. Effects of dietary concentrate levels based on whole-crop barley silage on chemical compositions of Korean black caprine meat

\begin{tabular}{|c|c|c|c|c|}
\hline Item $\quad$ Treatment $^{1)}$ & Control & BS 2.0 & BS 1.5 & BS 1.0 \\
\hline Moisture (\%) & $75.23 \pm 0.45$ & $75.17 \pm 0.54$ & $75.64 \pm 0.55$ & $75.09 \pm 0.49$ \\
\hline Crude protein (\%) & $22.01 \pm 0.46$ & $22.24 \pm 0.57$ & $22.21 \pm 0.83$ & $21.96 \pm 0.36$ \\
\hline Crude fat (\%) & $1.59 \pm 0.23$ & $1.86 \pm 0.23$ & $1.81 \pm 0.46$ & $1.56 \pm 0.38$ \\
\hline Crude ash (\%) & $1.04 \pm 0.25$ & $1.19 \pm 0.29$ & $1.17 \pm 0.30$ & $1.17 \pm 0.32$ \\
\hline
\end{tabular}

1) Control: Rice straw+concentrate $2.0 \%$,

BS 2.0: Whole-crop barley silage+concentrate $2.0 \%$, BS 1.5: Whole-crop barley silage+concentrate $1.5 \%$, BS 1.0: Whole-crop barley silage+concentrate $1.0 \%$ Data are expressed as mean \pm SD. 
Table 5. Effects of dietary concentrate levels based on whole-crop barley silage on physical properties of Korean black caprine meat

\begin{tabular}{|c|c|c|c|c|}
\hline Item $\quad$ Treatment $^{1)}$ & Control & BS 2.0 & BS 1.5 & BS 1.0 \\
\hline Shear force $\left(\mathrm{kg} / \mathrm{cm}^{2}\right)$ & $3.18 \pm 0.20^{\mathrm{a}}$ & $2.62 \pm 0.24^{\mathrm{b}}$ & $2.78 \pm 0.23^{\mathrm{b}}$ & $3.21 \pm 0.29^{\mathrm{a}}$ \\
\hline Cooking loss (\%) & $26.83 \pm 2.15$ & $25.63 \pm 1.53$ & $25.78 \pm 1.28$ & $27.16 \pm 2.05$ \\
\hline Water holding capacity (\%) & $52.05 \pm 1.45^{\mathrm{b}}$ & $55.26 \pm 1.57^{\mathrm{a}}$ & $55.22 \pm 1.26^{\mathrm{a}}$ & $52.01 \pm 1.18^{\mathrm{b}}$ \\
\hline Juiciness & $4.20 \pm 0.35$ & $4.60 \pm 0.00$ & $4.47 \pm 0.50$ & $4.13 \pm 0.23$ \\
\hline Tenderness & $4.47 \pm 0.46$ & $5.20 \pm 0.40$ & $4.80 \pm 0.43$ & $4.40 \pm 0.40$ \\
\hline Flavour & $3.67 \pm 0.23$ & $3.93 \pm 0.31$ & $3.87 \pm 0.11$ & $3.67 \pm 0.12$ \\
\hline
\end{tabular}

1) Control: Rice straw+concentrate $2.0 \%$,

BS 2.0: Whole-crop barley silage+concentrate 2.0\%, BS 1.5: Whole-crop barley silage+concentrate $1.5 \%$,

BS 1.0: Whole-crop barley silage+concentrate $1.0 \%$ Data are expressed as mean \pm SD.

a,b Values with different superscripts within the same row are significantly different $(\mathrm{p}<0.05)$.

방 및 회분의 함량이 각각 75.420 .81 .89 및 $1.31 \%$ 내외로 보고하여, 본 시험의 결과와 비 슷하였다.

Russo 등 (1999)은 양에게 농후사료 급여수준 을 증가시키면 공급되는 에너지 수준이 높아져 고기의 지방 함량이 높아진다고 보고하였고, 김과 서(2006)는 거세한우에게 청보리 사일리 지를 급여했을 경우에 볏짚 급여구 보다 고기 의 지방함량이 $16.3 \%$ 유의하게 높았다고 보고 하였는데, 본 결과에서도 농후사료 급여수준이 체중의 $1.5 \%$ 이상인 청보리 사일리지구에서 흑 염소 고기의 지방함량이 증가하는 경향을 보여 청보리 사일리지 급여와 함께 농후사료 수준 증가로 육질개선의 가능성을 시사하였다.

육질의 물리적 특성은 Table 5와 같으며 전 단력과 보수력은 $\mathrm{BS} 2.0$ 구와 $\mathrm{BS} 1.5$ 구가 각각 2.62 와 $2.78 \mathrm{~kg} / \mathrm{cm}^{2}$ 및 55.26 과 $55.22 \%$ 로 대조구 와 BS 1.0 구에 비해 유의하게 높게 나타났으며 $(\mathrm{p}<0.05)$, 가열감량에서 유의성은 나타나지 않 았으나 BS 2.0구와 BS 1.5구가 25.63과 25.78\% 로 높은 경향을 보였다.

관능검사 결과 중 다즙성, 연도 및 풍미는 각각 4.13 4.60, 4.40 5.20 및 3.67 3.93으로 처리구간 유의성은 나타나지 않았으나 청보리 사일리지 급여 시에 농후사료 급여수준이 높을 수록 우수한 경향으로 나타났다.

본 시험에서는 고기의 지방 함량이 높을수록
전단력이 유의하게 낮아졌는데, 이에 대해 Hodgson 등 (1992)은 전단력과 지방 함량과는 부의 상관관계를 밝히고 있어 농후사료 급여비 율이 높은 구에서 전단력이 낮아진 것으로 생 각된다. 또한 근내 지방도가 높을수록 보수력 도 높아진다고 보고하고 있어 (Palanska와 Nosal, 1991), 본 시험의 결과에서도 BS 2.0과 BS 1.5 구가 보수력이 높았던 것은 근내 지방 함량 (Table 4)이 높았기 때문으로 사료된다.

Ryan 등 (2007)은 농후사료 급여수준이 높을 때 고기의 향미가 증가되며, 김과 서 (2006)는 청보리 사일리지 급여 시 다즙성이 증가한다고 하였다. 본 결과에서도 관능검사 결과가 농후 사료 급여수준이 높고 청보리 사일리지를 급여 한 BS 2.0과 BS 1.5구에서 우수한 경향으로 나 타났다.

이상의 결과를 종합적으로 고려하여 판단할 때, 육성기 비육흑염소에 있어서 청보리 사일 리지를 급여 시 볏짚급여 보다 농후사료 절감 및 발육개선의 효과가 있었으며, 청보리 사일 리지를 조사료원으로 급여 시 육성기 흑염소의 생산성과 육질개선을 위한 농후사료 급여수준 은 $1.5 \%$ 가 적정한 것으로 사료된다.

IV. 요 약

본 시험은 청보리 사일리지 급여 시 농후사 
료 급여수준이 육성기 흑염소의 발육과 육질에 미치는 영향을 조사하였다. 시험은 흑염소 육 성축 수컷 36두를 공시하여 대조구는 볏짚과 농후사료 수준을 체중의 $2 \%$ 로 급여하고 처리 구는 청보리 사일리지와 농후사료 수준을 각각 체중의 2.0, 1.5 및 $1.0 \%$ 로 급여하여 2007년 5 월 14일부터 2007년 10월 12일까지 시험을 실 시하였으며 그 결과는 다음과 같다. 일당증체 량은 대조구 보다 BS 1.5와 BS 2.0구가 유의하 게 높게 나타났다 $(\mathrm{p}<0.05)$. 1 일 사료 섭취량은 대조구가 $689.3 \mathrm{~g}$ 으로 BS 1.0 구의 $585.5 \mathrm{~g}$ 보다 유의하게 높았지만 BS 2.0구의 $734.3 \mathrm{~g}$ 보다는 유의하게 낮게 섭취하였다 $(\mathrm{p}<0.05)$. 도체율과 정육율은 $\mathrm{BS} 2.0$ 과 $\mathrm{BS} 1.5$ 구가 대조구와 $\mathrm{BS}$ 1.0 구 보다 유의하게 높게 나타났다 $(\mathrm{p}<0.05)$. 전단력과 보수력은 BS 2.0구와 BS 1.5구가 우 수한 것으로 나타났으며 $(\mathrm{p}<0.05)$, 관능검사는 청보리 사일리지 급여 시 농후사료 급여수준이 높을수록 우수한 경향으로 나타났다. 이러한 결과를 종합적으로 고려할 때 청보리 사일리지 급여 시 육성기 흑염소의 발육과 육질개선을 위한 농후사료 급여수준은 $1.5 \%$ 가 적정한 것으 로 사료된다.

\section{$\mathrm{V}$. 인 용 문 헌}

1. Archimede, H., Pellonde, P., Despois, P., Etienne T. and Alexandre, G. 2008. Growth performances and carcass traits of Ovin Martinik lambs fed various ratios of tropical forage to concentrate under intensive conditions. Small Rumin. Res. 75:162-170.

2. A.O.A.C. 1990. Official methods analysis. Association of official analytical chemists. 15th edition. Washington, D.C.

3. Atti, N., Rouissi, H. and Mahouachi, M. 2004. The effect of dietary crude protein level on growth, carcass and meat composition of male goat kids in Tunisia. Small Rumin. Res. 54:8997.

4. Burke, J. M., Apple, J. K., Roberts, W. J. and Boger, C. B. 2003. Effect of breed-type on performance and carcass traits of intensively managed hair sheep. Meat Sci. 63:309-315.

5. Colomer-Rocher, F., Kirton, A. H., Mercer, G. J. K. and Duganzich, D. M. 1992. Carcass composition of New Zealand Saanen goats slaughtered at differents weights. Small Rumin. Res., 7:161-173.

6. Devendra, C. 1988. Meat production from goats in developing countries. BSAP, Edinburgh, UK. pp 395-406.

7. Haddad, S. G. 2005. Effect of dietary forage: concentrate ratio on growth performance and carcass characteristics of growing Baladi kids. Small Rumin. Res. 57:43-49.

8. Hodgson, R. R., Belk, K. E., Savell, J. W., Cross, H. R. and Williams, F. L. 1992. Develop meat of a quantitative quality grading system for mature cow carcasses. J. Anim. Sci. 70:1840.

9. Kawas, J. R., Lopes, J., Danelon, D. L. and Lu, C. D. 1991. Influence of forage - to - concentrate ratios on intake, digestibility, chewing and milk production of dairy goats. Small Rumin. Res. 4:11-18.

10. Lippke, H. 1980. Forage characteristics related to intake, digestibility and gain by ruminants. J. Anim. Sci. 50:952-961.

11. Mahgoub, O., Lu, C. D. and Early, R. J. 2000. Effects of dietary energy density on feed intake body weight gain and carcass chemical composition of Omani growing lambs. Small Rumin. Res. 37:35-42.

12. Manninen, M., Sankari, S., Jauhiainen, L., Kivinen, T., Anttila, P. and Soveri, T. 2008. Effects of outdoor winter housing and feeding level on performance and blood metabolites of suckler cows fed whole-crop barley silage. Livestock Science 115:179-194.

13. Mazumder, M. A. R., Hossain, M. M. and Akter, S. 1998. Effect of levels of concentrate supplement on live weight gain and carcass characteristics in sheep on restricted grazing. Asian-Aust. J. Anim. Sci. 11(1):17-20.

14. Meissner, H. H., Smuts, M. and Coertze, R. J. 
1995. Characteristics and efficiency of fastgrowing steers fed different dietary energy concentrations. J. Anim. Sci. 73:931-936.

15. Palanska, O. and Nosal, V. 1991. Meat quality of bulls and heifers of commercial crossbreeds of the improved Slovak Spotted cattle with the Limousine breed Vedecke Prace Vyskumneho Ustavu Zivocisnej Vyroby Nite (CSFR) 24:59.

16. Rhee, K. S., Waldron, D. F., Ziprin, Y. A. and Rhee, K. C. 2000. Fatty acid composition of goat diets vs. intramuscular fat. Meat Sci. 54:313-318

17. Russo, C., Preziuso, G., Casarosa, L., Campodoni, G. and Cianci, D. 1999. Effect of diet energy source on the chemical-physical characteristics of meat and depot fat of lamb carcasses. Small Rumin. Res. 33:77-85.

18. Ryan, S. M., Unruh, J. A., Corrigan, M. E., Drouillard, J. S. and Seyfert, M. 2007. Small Rumin. Res. 73:67-76.

19. SAS. 1991. User's Guide Statistics. Statistical Analysis System Institute Inc. Cary. NC.

20. Shaver, R. D., Satter, L. D. and Jorgensen, N. A. 1988. Impact of forage fiber content on digestion and digesta passage in lactating dairy cows. J. Dairy Sci. 71:1556-1565.

21. Van Soest, P. J. 1994. Nutritional Ecology of the Ruminant, 2nd edn. Cornell University Press, Ithaca, NY.

22. 김원호, 서 성. 2006. 총체보리를 중심으로 한 동 계사료작물의 재배 및 이용기술. 한국초지학회 2006년 학술 심포지엄. pp37-57.

23. 김원호, 서 성, 윤세형, 김기용, 조영무, 박태일, 고종민, 박근제. 2003. 사일리지용 우량 보리품종 선발 2. 사료가치 및 $\mathrm{TDN}$ 수량. 한국초지학회. 23(4):283-288.

24. 최순호, 김상우, 박범영, 상병돈, 김영근, 명정환, 허삼남. 2005. 사료의 조단백질 수준이 육성기 흑염소의 발육과 육질에 미치는 영향. 한국동물 자원과학회지. 47(5):783-788.

25. 최순호, 황보순, 김상우, 김영근, 상병돈, 명정환, 허삼남, 조익환. 2007. 사료의 에너지 수준이 육 성기 흑염소의 발육과 육질에 미치는 영향. 한국 동물자원과학회지. 49(4):509-514.

(접수일자 : 2008. 7. 16. / 수정일자 : 2008. 8. 18. / 채택일자 : 2008. 8. 20.) 